\title{
Characterization of volatile compounds responsible for the aroma in naturally fermented sausages by GC-olfactometry
}

Alicia Olivares, José Luis Navarro and Mónica Flores*

\author{
Alicia Olivares \\ Instituto de Agroquímica y Tecnología de Alimentos (IATA-CSIC), Spain \\ José Luis Navarro \\ Instituto de Agroquímica y Tecnología de Alimentos (IATA-CSIC), Spain \\ Mónica Flores \\ Instituto de Agroquímica y Tecnología de Alimentos (IATA-CSIC), Spain \\ Corresponding author: \\ Mónica Flores, Instituto de Agroquímica y Tecnología de Alimentos (IATA-CSIC), \\ Avda Agustín Escardino 7, 46980 Paterna (Valencia), Spain. \\ Email:mflores@iata.csic.es
}

Running head: Aroma compounds in fermented sausages 


\begin{abstract}
The objective of this study was to characterize naturally fermented dry sausages produced without the use of microbial starters and to determine which odour active compounds are responsible for their aroma. The traditional manufacture was responsible for different chemical characteristics and consumer's acceptance. The volatile compounds detected in the headspace comprised a complex mixture of volatile compounds derived from bacterial metabolism (mainly esterase activity of Staphyloccoci), spices and lipid auto-oxidation. The odour-active volatile compounds were identified using gas-chromatography coupled to olfactometry (GC-O) using the detection frequency method. The aroma profile was characterized by the presence of several compounds such as acetic acid, ethyl butanoate, hexanal, methional, 1-octen3-ol, benzeneacetaldehyde and 4-methyl-phenol. However, naturally fermented sausages were also characterized by numerous esters, both ethyl and methyl esters, which impart a wide variety of fruity notes.
\end{abstract}

\title{
Keywords
}

Sausage, fermentation, aroma, volatile compounds, GC-olfactometry. 


\section{INTRODUCTION}

The traditional manufacture methods of naturally fermented sausages and their singular organoleptic attributes distinguish them from others of the same category and make them highly appreciated by consumers. They are processed through a natural fermentation without the use of starter cultures and by drying in room chambers. A wide variety of traditional dry sausages are produced in the Mediterranean area, often at local or regional level (Talon and others 2008). In the east of Spain, small factories manufacture naturally fermented sausages "Embutido de Requena" (Requena, Valencia, Spain) through a natural fermentation process by indigenous bacteria and using low temperatures during processing $\left(10-12^{\circ} \mathrm{C}\right)$.

Previous research has been done to characterize the microorganisms involved in the fermentation on naturally fermented sausages (Aymerich and others 2003; Talon and others 2008). Also, the changes of the lipid fraction that contribute to their final sensory quality have been studied (Navarro and others 2001). Nevertheless, few works have studied the volatile compounds present in naturally fermented sausages, (Croizet and others 1992; Mateo and Zumalacárregui 1996; Schmidt and Berger 1998a; Di Cagno and others 2009). Although in some cases it is no clear if the sausages were manufactured using a starter (Meynier and others 1999; Schmidt and Berger, 1998b; Ansorena and others 2001; Blank and others 2001).

Among the hundreds of volatile compounds identified in dry-fermented sausages only a limited number are present at a concentration higher than its threshold value contributing to the aroma. A few works have studied the aroma active compounds in dry fermented sausages (Stahnke, 1994; Schmidt and Berger, 1998b; Meynier and others 1999; Marco and others 2007; Olivares and others 2011). However, only Croizet and others (1992), Schmidt \& Berger (1998a) and Söllner and Schieberle, (2009) have studied aroma compounds in naturally fermented sausages. Nevertheless, the relationship between aroma active compounds of naturally fermented sausages and their consumer acceptability has never been established. Therefore, the main objective 
of this study was to study differences among naturally fermented Spanish dry sausages ("Embutido de Requena") and to determine which odour active compounds are responsible for their aroma.

\section{MATERIALS AND METHODS}

\section{Materials}

Naturally fermented dry sausages ("Embutido de Requena”) from 10 different manufacturers (ER-1 to ER-10) were supplied by the "Consejo Regulador de la Indicación Geográfica Protegida Embutido de Requena” (Requena, Valencia, Spain). Artisan sausages were manufactured under the traditional specifications; no starter cultures were added and the drying process was carried out in room temperature chambers at low temperatures (approximately $10-12{ }^{\circ} \mathrm{C}$ ). The naturally fermented sausages were dried for approximately 1 month. The weight of naturally fermented sausages was $200-350 \mathrm{~g}$ and the diameter ranged from 30 to $40 \mathrm{~mm}$. All the sausages were manufactured using lean pork meat, pork back fat, sodium chloride, nitrite, nitrate, sugars, dextrin, spices and different additives such as colorants (Ponceau 4R, carminic acid) and proteins (milk and soya). Three sausages from each "Salchichón de Requena" manufacturer (ER-1 to ER-10) were sliced, vacuum packed and frozen at $-20^{\circ} \mathrm{C}$ for subsequent chemical, lipid and volatile analyses. Three sausages from each manufacturer were used for the consumer analysis. Results were expressed as the mean of three replicates in dry matter $(\mathrm{dm})$.

\section{Methods}

Moisture, total lipids, protein, $\mathrm{pH}$, TBARS, nitrate and nitrite and free fatty acids analyses. Moisture content was determined according to the official method for analysis of meat products by dehydration at $100^{\circ} \mathrm{C}$ until constant weight (BOE, 1979).

Total lipids were extracted from $5 \mathrm{~g}$ of minced sausage according to the method of Folch and others (1957), using dichloromethane:methanol (2:1) instead of 
chloroform:methanol (2:1) as solvent due to its lower toxicity. The extracts were dried in a rotating vacuum evaporator and weighed to determine the total lipid quantity. Free fatty acids were analyzed as described Olivares and others (2011).

Nitrogen content was determined by the Kjeldahl method. The $\mathrm{pH}$ was measured as described by ISO 2917:1974 by introducing a pH-meter (HI 99163, Hanna Intruments Inc., Hoonsocket, USA) into a sausage : water mixture (1:1). Thiobarbituric acid reactive substances (TBARS) were determined according to Bruna and others (2001), using tricloroacetic acid instead of perchloric acid as solvent. The nitrate and nitrite content was determined using an enzymatic kit (Cat. No. 09050658, Roche, Palo Alto, USA) according to Arneth and Herold (1988).

Analysis of headspace volatile compounds. Extraction of headspace (HS) volatile compounds was done using a solid phase microextraction (SPME) device (Supelco, Bellefonte, PA, USA) as described Olivares and others (2011). $3 \mathrm{~g}$ of minced sausage was weighted into a $10 \mathrm{~mL}$ headspace vial, and $0.75 \mathrm{mg}$ of $\mathrm{BHT}$ was added. The vial was left for $1 \mathrm{~h}$ in a thermoblock (J.P., Selecta, Barcelona, Spain) at $37^{\circ} \mathrm{C}$ for equilibration. The CAR/PDMS fibre was then exposed to the headspace for $3 \mathrm{~h}$ while maintaining the sample at $37^{\circ} \mathrm{C}$. For the identification of the volatile compounds, a gas chromatograph HP 7890A equipped with an HP 5975C mass selective detector (Hewlett Packard, Palo Alto, CA) using the same conditions as described Olivares and others (2011). The compounds were identified by comparison with mass spectra from the library database (Nist' 05), kovats retention index (Kovats, 1965) and by comparison with authentic standards. The standards used for the identification were all obtained from Fluka Chemie AG (Buchs, Switzerland) except (Z)-2-nonenal, (Z)-2-octenal, (Z,Z)2,4-heptadienal, diacetyl, 2-methylpyrazine, benzeneacetaldehyde, methyl acetate, methyl 2-hydroxy-propanoate, and 4-methyl-phenol which were obtained from Aldrich (St. Louis, MO). Quantification was based on the total FID area. The results were 
expressed as area units present in the headspace of sausage and comprised the mean of three replicates from each manufacturer.

The identification of aroma-active compounds was done by SPME-GC-Olfactometry (SPME-GC-O) as described Olivares and others (2011). The detection frequency method was used to estimate the aromatic impact of each volatile compound and two trained assessors evaluated the 10 naturally fermented sausages, therefore a total of 20 assessments were carried out.

Consumer sensory Evaluation. The acceptability of naturally fermented sausages was evaluated by 78 consumers. The analysis was carried out in a sensory laboratory equipped with individual booths (ISO 8589, 1988) as described Olivares and others (2011). The consumers were asked to evaluate each sausage based on appearance, aroma, hardness, juiciness, taste and overall quality using a 9-point hedonic scale. The analysis was done in two different sessions to avoid fatigue of the panelists due to the high number of samples, 5 samples in each session. Sensory evaluations were recorded by computer software using Compusense ${ }^{\circledR}$ five release 5.0 (Compusense Inc., Guelph, ON, Canada).

Statistical analysis. Data from chemical, free fatty acids, volatile and consumer analyses were analyzed by one-way analysis of variance (ANOVA) in order to determine differences among manufacturers. Differences between particular sample means were analyzed according to Fisher's least significant difference (LSD) test. Also, a Pearson correlation procedure was performed to evaluate any relationship between chemical and volatile compounds parameters. Furthermore, principal component analysis (PCA) was used to find the relationships among sausage manufacturers (ER-1 to ER-10) and chemical parameters. Statistical analysis was performed using the statistical software XLSTAT, 2009.4.03 (Addinsoft, Barcelona, Spain). 


\section{RESULTS AND DISCUSSION}

Moisture, total lipids, protein, pH, TBARS, nitrate and nitrite and free fatty acids analyses.

Table 1 shows the composition and chemical characteristics of Requena naturally fermented sausages produced by different manufacturers. The water content of naturally fermented sausages ranged from 24.6 to $35.6 \%$ while fat and protein contents ranged from 28.7 to $55.2 \%$ and 32.3 to $53.7 \%$ in dry matter (dm), respectively. Moisture, lipid and protein content are within the range expected for dry fermented sausages (Wirth, 1988), although the variability among sausages can be due to the raw materials used and also to differences in the traditional manufacturing practices.

In relation to $\mathrm{pH}$, all the sausages were above $\mathrm{pH} 5.0$ and all of them were between 5.3 and 6.05, except ER-4 (Table 1). Therefore "Salchichón de Requena" sausages can be considered as low-acid sausages (Aymerich and others 2003).

TBARS is used to evaluate the extent of the lipid oxidation process by measuring secondary lipid oxidation products. The TBARS values ranged from 0.6 to $2.8 \mathrm{mg}$ malonaldehyde (MDA) per $\mathrm{Kg} \mathrm{dm}$ and it is within the range expected for ripened sausages (Marco and others 2006). The lipid oxidation process that takes place during the ripening of dry sausages is essential for the development of typical aroma (Gandemer, 2002). Highest lipid oxidation values were detected in sausages that contained the highest amount of fat except for ER-4 sausage $(r=0.865, p=0.003)$ in accordance to other studies where high oxidation values were related to high fat contents (Liaros and others 2009, Olivares and others 2011).

The nitrate content differed significantly between the sausages (Table 1). The concentrations ranged from 10.7 to $535.6 \mathrm{ppm}(\mathrm{dm})$. Five naturally fermented sausages (corresponding to manufacturers ER-1, ER-2, ER-3, ER-4 and ER-5) showed high nitrate residual levels above the maximum residual limit $(250 \mathrm{ppm})$. With respect to nitrite, only residual levels were found as other study reported (Meynier and others 1999). 
In summary, the composition and chemical characteristics were different among naturally fermented sausages obtained from the different manufacturers, mainly due to differences in composition and the high nitrate residual level observed in several of them.

The total concentration of free fatty acids (FFA) in the naturally fermented sausages ranged from 1066.4 to $3211.1 \mathrm{mg} / 100 \mathrm{~g} \mathrm{dm}$ (Table 2) which represented 2.5-8.0\% of the total lipid content. A similar FFA concentration was observed by Zanardi and others (2004) in dry fermented sausages. The FFA relationship detected in the sausages was MUFA>PUFA>SFA (Navarro and others 2001). However, Gandemer (2002) reported that the free fatty acid composition of back fat from industrial pigs was MUFA>SFA $>$ PUFA. Therefore, it is supposed that the free fatty acid profile observed in this study was the consequence of the preferential release of the unsaturated fatty acids from the sausage lipids during ripening of sausages (Navarro and others 2001; Zanardi and others 2004).

In summary, the FFA profile was similar among sausages, although several of them showed lower FFA concentration. The differences in FFA among naturally fermented sausages are probably due to differences in the processing conditions among manufacturers such as grinding, stuffing, and the natural fermentation.

\section{Analysis of headspace volatile compounds.}

A total of 99 volatile compounds were identified by GC-MS in the HS of sausages and their structures were confirmed using authentic standards. However, several compounds could not be totally resolved and were quantified in the GC-FID as a mixture of volatile compounds (Table 3). Moreover, 4 compounds were not quantified in the sausages HS due to its low concentration (methanethiol, butanoic acid, 1-octen-3-ol and phenylethyl alcohol). The compounds detected were 27 esters, 19 aldehydes, 14 hydrocarbons, 9 alcohols, 9 acids, 8 ketones, 7 terpenes, 3 sulphur compounds, 2 pyrazines and 1 lactone. All of them have been previously identified in dry fermented sausages (Meynier 
and others 1999; Schmidt and Berger, 1998; Ansorena and others 2001) except methyl benzeneacetate and methyl nonanoate.

The abundance of the volatile compounds is shown in Table 3, where the volatile compounds are grouped according to their possible origin: lipid auto-oxidation, bacterial metabolism (lipid $\beta$-oxidation, carbohydrate fermentation, amino acid degradation, and staphylococci esterase activity), spices and unknown origin (meat or food contaminants). However, several of the compounds listed can have more than one origin (Ordóñez and others 1999). With our extraction technique (SPME CAR/PDMS), the compounds extracted in higher amounts were those derived from lipid autooxidation, esterase activity of Staphylococci and spices (Figure 1). However, the proportion of volatile compounds obtained depends on the stationary phase of the SPME fibre employed and the extraction conditions used (time, temperature, etc). Therefore, the HS abundance and volatile compounds profile can not be compared with other studies which employed other extraction techniques such as dynamic headspace (Croizet and others 1992) and distillation techniques (Mateo \& Zumalacárregui, 1996; Schmidt \& Berger, 1998a) or other SPME extraction conditions (Di Cagno and others 2008; Spaziani and others 2009).

Lipid oxidation was responsible for the generation of volatile compounds mainly by autooxidation process as lipid auto-oxidation products comprised $14.5-34-4 \%$ of the total extracted area whilst lipid $\beta$-oxidation (produced mainly by Staphylococci as part of their metabolism) only generated $0.17-0.59 \%$ (data not shown). The manufacturers with the highest lipid derived compounds were ER-3, and ER-5 (Table 3). In this volatile group, the compounds that showed the highest abundance were hexanal, octanal, hexanoic acid, (Z,Z)-2,4-heptadienal and nonanal (Table 3). Using the same extraction technique Marco and others (2006) reported up to $45 \%$ of the extracted area of lipid auto-oxidation products in dry fermented sausages elaborated with starter culture that it is higher than the values obtained in naturally fermented sausages. However, the relative abundance obtained is in agreement with other naturally fermented sausages where the percentage 
of lipid auto-oxidation volatile compounds was around $25 \%$ although using different extraction techniques (Mateo and Zumalacárregui, 1996; Di Cagno and others 2008; Spaziani and others 2009). In general, lipid derived volatile compounds represent one of the main groups in naturally fermented sausages although their relative importance is lower than in other fermented sausages. This fact could be due to the low temperatures applied during naturally fermented sausage processing, since lipid auto-oxidation is increased by temperature (Stahnke, 1995).

The volatiles generated from the carbohydrate fermentation represented $4.9-25.8 \%$ of the total extracted area (data not shown), although only ER-7 and ER-10 showed percentages above $20 \%$. In this group, the compound extracted in the highest proportion was acetic acid (Table 3), although acetone was the most abundant compound in ER-3. It was observed an opposite relationship between acetic acid abundance and $\mathrm{pH}$ value, except in the manufacturer ER-4, since higher acetic acid abundance was related to lower $\mathrm{pH}$ (Pearson coefficient $\mathrm{r}=-0.7, \mathrm{p}=0.033$ ). In general, the relative abundance of acetic acid in naturally fermented sausages is low compared to starter added sausages (Mateo \& Zumalacárregui, 1996). Other authors also reported a low proportion of acetic acid in naturally fermented sausages (Schmidt \& Berger, 1998a; Di Cagno and others 2008).

The volatile compounds originated from the amino acid degradation comprised 2.5-5.2 $\%$ of the total extracted volatile compounds (data not shown). The most abundant compounds in this group were 2-methyl butanoic acid, benzaldehyde, phenol and benzeneacetaldehyde (Table 3), which have been also detected in other naturally fermented sausages (Mateo and Zumalacárregui, 1996; Di Cagno and others 2008). The lowest abundance of this group was found in the sausages ER-5 and ER-8, mainly due to its lower abundance of benzaldehyde.

Esters were detected as the most abundant group of volatile compounds arising from microbial metabolism since they represented $17.6-44.1 \%$ of the total extracted area (Figure 1). Within the sausages, ER-6, ER-7 and ER-8 showed the highest ester 
abundance. Two different types of ester compounds were identified; methyl and ethyl esters (Table 3). The methyl esters present in highest abundance were methyl acetate, methyl butanoate and methyl hexanoate (Table 3). Among the 12 methyl esters identified, 10 have been previously found in dry fermented sausages, except for methyl benzeneacetate and methyl nonanoate (Schmidt and Berger, 1998). The origin of methyl esters is not reported in the literature. Bruna and others (2001) remarked the ability of Penicillium strains to produce ethyl esters. However, Olivares and others (2011) also detected the presence of methyl esters in dry fermented sausages in which natamycin and potassium sorbate were added to prevent mould growth, therefore the generation of methyl esters could be attributed to Staphyloccoci (Montel and others 1998). With respect to ethyl esters, with our extraction technique, the most abundant ethyl esters in naturally fermented sausages were ethyl acetate and ethyl 2-methyl butanoate (Table 3).

The compounds derived from spices were mainly terpenes (Table 3) and represented $10.2-34.6 \%$ of the total extracted area (Figure 1) being ER-7 sausage the one with the lowest terpene abundance. In all the sausages, the most abundant compounds were $\beta$ myrcene, 3-carene and caryophyllene (Table 3), which are derived from pepper (Croizet and others 1992). The variability observed in the content of terpenes can be ascribed to the different amount and kind of spices added (Ordoñez and others 1999) as it was observed that some manufacturers used minced pepper while others used it as a whole grain. Spaziani and others (2009) detected terpenes as the most abundant class of aroma compounds ( $95 \%$ of the total extracted area) due to the spices added, mainly pepper and garlic, in natural Italian fermented sausages, although this was probably due to the extraction conditions employed. However, the high proportion of terpenes has also been described in other naturally fermented sausages in contrast to sausages with starter culture addition where other volatile compounds derived from biochemical reactions were dominant (Schmidt \& Berger, 1998a; Di Cagno and others 2008). In Requena naturally fermented sausages, volatile compounds derived from spices 
showed an important proportion of the extracted area, although they were not the main chemical class.

\section{Aroma-active volatile compounds}

The HS of naturally fermented sausages comprised a complex mixture of volatile compounds as described above. In order to determine the impact odorants responsible for their singular aroma the HS was analyzed by GC-O using the detection frequency (DF) method (Zellner and others 2008). A total of 42 odour-active regions were detected, although 11 of them could not be identified (Table 4, Figure 1), probably due to their low concentration but extremely low odour thresholds to be able to be detected by smell. All the aroma compounds identified have already been detected as odour active compounds in dry fermented sausages (Schmidt and Berger, 1998a; Meynier and others 1999; Marco and others 2007; Söllner and Schieberle, 2009) except for several esters (ethyl 2-OH-propionate, methyl 3-methyl butanoate, methyl benzoate and methyl benzeneacetate).

The detection frequency (DF) method assumes that the compounds detected more frequently have a greater relative importance. In this sense, only 6 compounds presented DF values higher than 16: acetic acid (vinegar), ethyl butanoate (strawberry, fruity), 1-octen-3-ol (mushroom), benzeneacetaldehyde (roses), 4-methyl phenol (stable) and one unknown compound defined as meat broth and savoury. In addition, sixteen compounds had DF values between 10 and 15: ethyl 2-methyl propanoate (strawberry), methyl 3-methyl butanoate (fruity), hexanal (fresh cut grass), butanoic acid (cheese), methional (cooked potato), (Z)-2-heptenal (unpleasant), ethyl hexanoate (flowery, sweet), a-terpinene (wood, metallic), caryophyllene (spicy, cloves) and 7 unknown compounds which contributed to the aroma with roasted nuts, toasted, woody and dissolvent notes. Within the volatile compounds with DF values below 10, it is worthy of note the high proportion of ester compounds both ethyl and methyl esters which impart a wide variety of fruity notes. Although methyl esters were more abundant than ethyl 
esters (Table 3), most of the odour active esters were ethyl esters (Table 4) due to the higher thresholds of methyl esters than the ones of ethyl esters (Burdock, 2002). However, three methyl esters, methyl butanoate, methyl benzoate and methyl benzeneacetate, were identified as odour active compounds.

Many of the compounds which showed the highest HS abundance were detected as odour active (hexanal, octanal, acetic acid, benzeneacetaldehyde, ethyl acetate, methyl butanoate and ethyl 2-methyl butanoate, Table 3). However, the contribution of volatile compound to the aroma depends not only in HS abundance but also in perception threshold value. In this sense, several compounds were detected as important contributors due to their very low threshold values although they were extracted in low amounts ((Z)-2-heptenal, methional, 4-methyl phenol) or even not quantified (butanoic acid and 1-octen-3-ol) (Table 3).

Among the volatile compounds identified as odour-active in dry fermented sausages in previous studies, some of them have been selected as the most potent because they presented the highest DF values using detection frequency method or the highest dilution factors in dilution techniques (Zellner and others 2008). In this sense, the most potent odorants of naturally fermented sausages were acetic acid, ethyl butanoate, 1octen-3-ol, benzeneacetaldehyde, 4-methyl phenol and methional also described as essential contributors to the aroma of dry fermented sausages (Stahnke, 1994; Schmidt and Berger, 1998a; Meynier and others 1999; Marco and others 2007; Söllner and Schieberle, 2009).

In naturally fermented sausages, only three studies have analyzed the odour-active compounds present. Firstly, Croizet and others (1992) indicated that sulphur compounds, acetic acid, diacetyl, linear and branched aldehydes were the main odorants in naturally fermented sausages, although these authors only described the aromas eluted from the GC but did not establish the most potent odorants. Secondly, Schmidt \& Berger (1998a) reported the contribution of the spicy odour-active compounds derived from pepper and garlic (methylallysulphide, diallylsulphide, 
diallyldisulphide and eugenol), but did not show the aroma compounds produced by biochemical reactions the latter being described as typical of the starter culture sausages. Finally, Söllner and Schieberle (2009) reported the compounds with the highest odour activity values (OAV) of Hungarian type salami as acetic acid, acetaldehyde, methional, phenylacetaldehyde, 2-metoxyphenol and 2-acetyl-1-pyrroline. This is in accordance with our results as acetic acid, bencenoacetaldehyde (phenyl acetaldehyde) and methional were also found as high aroma impact compounds in our naturally fermented sausages (table 4). On the other hand, compounds such as 2metoxyphenol derived from the smoking process were not present in Requena sausages as they are not smoked. However, Requena naturally fermented sausages aroma was characterized by a high proportion of volatile compounds coming from biochemical pathways and to a lesser extent by spice-derived compounds.

\section{Consumer sensory evaluation}

In general, naturally fermented sausages were similar in sensory acceptance (Table 5). However, the ER-4 sausage was the less preferred by consumers in terms of hardness, juiciness, taste and overall acceptability $(p<0.05)$ and ER-5 sausage in terms of aroma $(p<0.05)$.

\section{Principal Components Analysis}

In order to establish which aroma compounds were responsible for the aroma of the naturally fermented sausages, a principal component analysis (PCA) was performed using the following parameters; lipolysis (FFA divided in SFA, MUFA and PUFA content), lipid oxidation (TBARS), aroma compounds abundance (only those compounds listed in Table 4). Results from PCA applied to mean scores of the parameters are summarized in Figure 2. The PCA showed that about $52.73 \%$ of the variability was explained by the two first principal components. Principal component 1 
(PC 1) was the most important variable in terms of differences among samples as it accounted for $30.41 \%$ of the total variability.

PC1 was positively related to several ester compounds such as ethyl acetate, ethyl butanoate, ethyl 2-methyl propanoate, ethyl 2-hydroxy-propanoate, ethyl decanoate and methyl 3-methyl butanoate. In addition, PC1 was inversely related to octanal and the aldehydes (Z)-2-heptenal and 2-methylpropanal. On the other hand, principal component 2 (22.32\%) was positively related to free fatty acids (SFA, MUFA and PUFA) and the aroma compounds acetic acid, a-terpinene, ethyl 2-methyl butanoate and ethyl hexanoate, and inversely to lipid oxidation value (TBARS), heptanal and hexanal.

\section{CONCLUSIONS}

Naturally fermented sausages from different manufacturers (Requena, Valencia, Spain) studied in this manuscript had different consumer acceptance and chemical characteristics. There was a wide variability among them that produced different consumer's acceptance probably due to the traditional manufacture process (i.e. gridding, stuffing and natural fermentation). Naturally fermented sausages were characterized by high free fatty acid content and high proportion of volatile compounds derived from lipid auto-oxidation, Staphylococci esterase activity, and spices. Among the volatile compounds, 31 were identified as odour active. The most odour active compounds were acetic acid, ethyl butanoate, hexanal, methional, 1-octen-3-ol, benzeneacetaldehyde and 4-methyl-phenol. However, the HS of the naturally fermented sausages was also characterized by numerous esters, both ethyl and methyl esters which impart a wide variety of fruity notes.

\section{References}

Ansorena D, Gimeno O, Astiasarán I, Bello J. (2001). Analysis of volatile compounds by GC-MS of a dry fermented sausage: chorizo de Pamplona. Food Research International, 34: 67-75. 
Arneth W, Herold B. (1988). Nitrat/Nitrit-Bestimmung Wurstwaren nach enzymatischer Reduktion, Fleischwirtschaft, 68: 761-764.

Aymerich T, Martín B, Garriga M, Hugas M. (2003). Microbial quality and direct PCR identification of lactic acid bacteria and nonpathogenic staphylococci from artisanal low-acid sausages. Applied Enviromental Microbiology 69: 4583-4594.

Blank I, Devaud S, Fay LB, Cerny C, Steiner M, Zurbriggen B. (2001). Odor-active compounds of dry cured meat: Italian-type salami and Parma ham. In: Aroma-Active Compounds in Foods. Chemistry and Sensory Properties. G. Takeoka, M. Güntert, K.H. Engel (Eds.). Washington DC, American Chemical Society, 9-20.

BOE (1979). Métodos oficiales de análisis de productos cárnicos. Boletín Oficial del Estado, de 28 de agosto de 1979, Anexo II, 20233-20240. Madrid, Spain.

Bruna JM, Ordoñez JA, Fernández M, Herranz B, de la Hoz L. (2001). Microbial and physico-chemical changes during the ripening of dry fermented sausages superficially inoculated with or having added an intracellular cell-free extract of Penicillium aurantiogriseum. Meat Science, 59: 87-96.

Bruna JM, Hierro EV, de la Hoz L, Mottram, DS, Fernández M, Ordóñez, JA. (2001). The contribution of Penicillium aurantiogriseum to the volatile composition and sensory quality of dry fermented sausages. Meat Science, 59: 97-107.

Burdock GA. (2002). Fenaroli's handbook of flavor ingredients, 4th ed. Boca Raton, Florida. CRC Press Inc.

Croizet F, Denoyer C, Tran N, Berdagué JL. (1992). Les composes volatils du saucisson sec. Évolution au cours de la maduration. Viandes Produits Carnés 13: 167-170.

Di Cagno R, Chaves López C, Tofalo R, Gallo G, De Angelis M, Paparella A, Hammes WP, Gobbetti M. (2008). Comparison of the compositional, microbiological, biochemical and volatile profile characteristics of three Italian PDO fermented sausages. Meat Science, 79: 224-235. 
Folch J, Lees M, Sloane Stanley GH (1957). A simple method for isolation and purification of total lipids from animal tissues. Journal of Biological Chemistry 226: 497-508.

Gandemer G. (2002). Lipids in muscles and adipose tissues, changes during processing and sensory properties of meat products. Meat Science, 62: 309-321.

ISO 2917. (1974). Meat and Meat Products. Determination of the $\mathrm{pH}$. Reference method.

ISO 8589. (1988). Sensory analysis. General guidance for design of test rooms. Standard no. 8589. Geneva, Switzerland.

Liaros NG, Katsanidis E, Bloukas JG. (2009). Effect of ripening time under vacuum and packaging film permeability on processing and quality characteristics of low-fat fermented sausages. Meat Science, 83: 589-598.

Marco A, Navarro JL, Flores M. (2006). The influence or nitrite and nitrate on microbial, chemical and sensory parameters of show dry fermented sausage. Meat Science, 73 : 660-673.

Marco A, Navarro JL, Flores M. (2007). Quantification of Selected Odor-Active Constituents in Dry Fermented Sausages Prepared with Different Curing Salts. Journal of Agricultural and Food Chemistry, 55: 3058-3065.

Mateo J, Zumalacárregui JM. (1996). Volatile compounds in chorizo and their changes during ripening. Meat Science, 44: 255-273.

Meynier A, Novelli E, Chizzolini R, Zanardi E, Gandemer G. (1999). Volatile compounds of commercial Milano salami. Meat Science, 51: 175-183.

Montel MC, Masson F, Talon R. (1998). Bacterial role in flavour development. Meat Science, 49, S111-S123.

Navarro JL, Nadal MI, Nieto P, Flores J. (2001). Effect of nitrate and nitrite curing salts on the generation and oxidation of fatty acids in non-fermented sausages. European Food Research and Technology, 212: 421-425. 
Olivares A, Navarro JL, Flores, M. (2011). Effect of fat content on aroma generation during processing of dry fermented sausages. Meat Science, 87: 264-273.

Ordóñez JA, Hierro EV, Bruna JM, de la Hoz L. (1999). Changes in the Components of Dry-Fermented Sausages during Ripening. Critical Reviews in Food Science and Nutrition, 39: 329-367.

Schmidt S, Berger RG (1998a). Microbially formed aroma compounds during the maturation of dry fermented sausage (Salami). Advances in Food Science 20: 144152.

Schmidt S, Berger RG (1998b). Aroma compounds in fermented sausages of different origins. Food Science and Technology-LWT, 31: 559-567.

Söllner K, Schieberle P. (2009). Decoding the Key Aroma Compounds of a HungarianType Salami by Molecular Sensory Science Approaches. Journal of Agricultural and Food Chemistry, 57: 4319-4327.

Spaziani M, Del Torre M, Stecchini MR. (2009). Changes of physicochemical, microbiological, and textural properties during ripening of Italian low-acid sausages. Proteolysis, sensory and volatile profiles. Meat Science, 81: 77-85.

Stahnke LH (1994). Aroma components from dried sausages fermented with Staphylococcus xylosus. Meat Science, 38: 39-53.

Stahnke LH (1995). Dried sausages fermented with Staphylococcus xylosus at different temperatures and with different ingredient levels - Part III. Sensory evaluation. Meat Science, 41: 211-223.

Talon R, Leroy S, Lebert I, Giammarinaro P, Chacornac JP, Latorre-Moratalla M, VidalCarou C, Zanardi E, Conter M, Lebecque A. (2008). Safety improvement and preservation of typical sensory qualities of tradicional dry fermented sausages using autochthonous starter cultures. International Journal of Food Microbiology 126: 227234.

Wirth F. (1988). Technologies for making fat-reduced meat products. Fleischwirtsch 68 : 1153-1156. 
Zanardi M, Ghidini S, Battaglia A, Chizzolini R. (2004). Lipolysis and lipid oxidation in fermented sausages depending on different processing conditions and different antioxidants. Meat Science, 66: 415-423.

Zellner BA, Dugo P, Dugo G, Mondello L. (2008). Gas chromatography-olfactometry in food flavour analysis. Journal of Chromatography A, 1186: 123-143.

\section{Acknowledgements}

Financial support from AGL 2009-08787 from MINECO (Spain), Prometeo 2012-001 (GVA) and FEDER funds are fully acknowledged. The predoctoral scholarship from GVA (Generalitat Valenciana, Spain) to A. Olivares is also acknowledged. The authors thank the Consejo Regulador de la Indicación Geográfica Protegida "Embutido de Requena" for the supplied samples, and are grateful to M. P. Valero for technical assistance.

\section{Figure Legends}




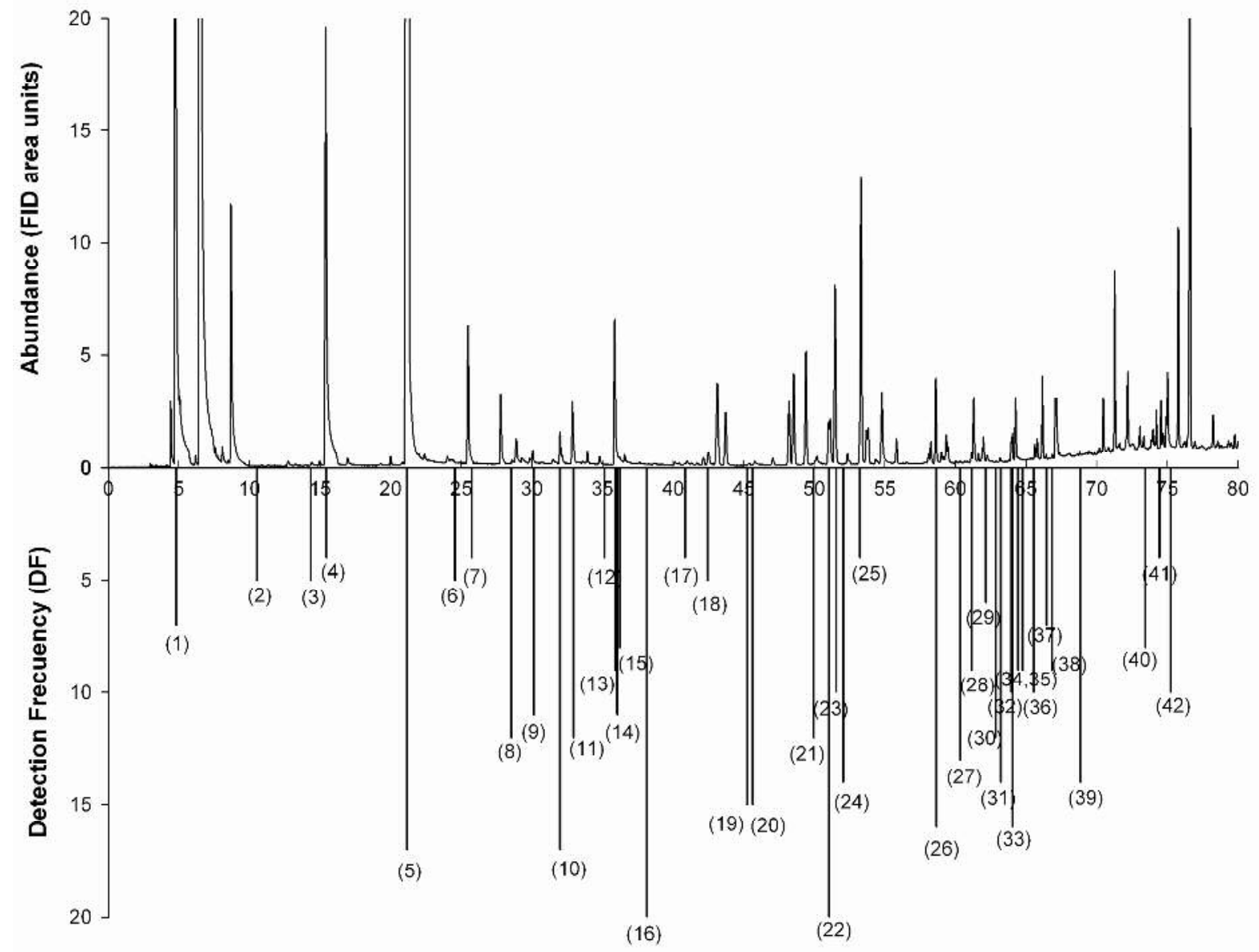

Figure 1. Aromagram of naturally fermented sausages. Numbers corresponds to the aroma described and indicated in table 4. 


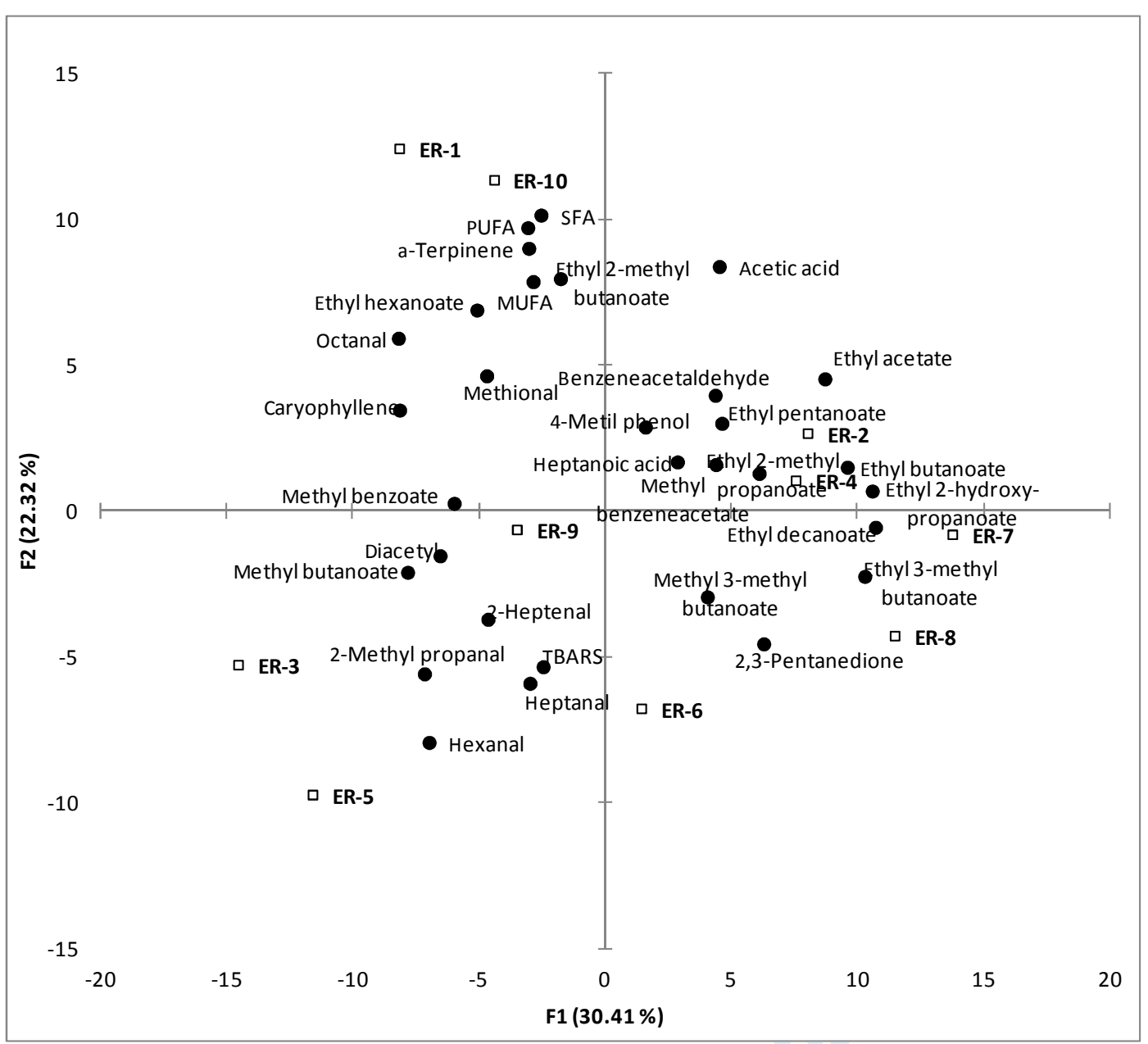

Figure 2. Loadings of the first two principal components (PC1-PC2) of the selected variables $(\bullet)$ and naturally fermented sausage samples (ER-1 to ER-10) (口). The selected variables were the aroma-active volatile compounds, TBARS and free fatty acids (SFA, MUFA, PUFA). 
Table 1. Composition and chemical characteristics of naturally fermented

sausages.

\begin{tabular}{|c|c|c|c|c|c|c|c|}
\hline Samples & $\begin{array}{l}\text { \% water } \\
(g / 100 \mathrm{~g})\end{array}$ & $\begin{array}{c}\% \text { fat } \\
(g / 100 \mathrm{~g} \mathrm{dm})\end{array}$ & $\begin{array}{l}\text { \% protein } \\
(\mathrm{g} / 100 \mathrm{~g} \mathrm{dm})\end{array}$ & $\mathrm{pH}$ & $\begin{array}{c}\text { TBARS } \\
\left(\mathrm{mg} \mathrm{MDA}^{*} / / \mathrm{kg}\right. \\
\mathrm{dm})\end{array}$ & $\begin{array}{l}\text { Nitrate } \\
\text { (ppm dm) }\end{array}$ & $\begin{array}{c}\text { Nitrite } \\
\text { (ppm dm) }\end{array}$ \\
\hline ER-1 & $29.40 \mathrm{c}$ & 39.94 bc & $43.36 \mathrm{c}$ & $5.56 \mathrm{~b}$ & $1.34 \mathrm{c}$ & $206.72 \mathrm{bcd}$ & $10.47 \mathrm{bc}$ \\
\hline ER-2 & $33.28 \mathrm{~b}$ & $33.10 \mathrm{~d}$ & 53.73 a & $5.55 \mathrm{~b}$ & $1.01 \mathrm{~cd}$ & $499.94 \quad$ a & $11.06 \mathrm{~b}$ \\
\hline ER-3 & $28.12 \mathrm{~cd}$ & 40.99 bc & $37.71 \mathrm{~d}$ & $6.00 \mathrm{a}$ & $1.28 \mathrm{c}$ & 535.65 a & $12.47 \mathrm{a}$ \\
\hline ER-4 & $31.80 \mathrm{~b}$ & 55.18 a & $32.27 \mathrm{e}$ & $5.08 \mathrm{~d}$ & $0.76 \mathrm{~d}$ & $336.18 \mathrm{~b}$ & $9.78 \mathrm{c}$ \\
\hline ER-5 & $24.66 \mathrm{e}$ & $44.75 \mathrm{~b}$ & $36.96 \mathrm{~d}$ & $6.00 \mathrm{a}$ & $2.08 \mathrm{~b}$ & 269.43 bc & $9.98 \mathrm{c}$ \\
\hline ER-6 & $27.06 \mathrm{~d}$ & 51.45 a & $35.64 \mathrm{~d}$ & $6.05 \mathrm{a}$ & $2.78 \mathrm{a}$ & $10.73 \mathrm{e}$ & $11.14 \mathrm{~b}$ \\
\hline ER-7 & $33.77 \mathrm{ab}$ & $42.32 \mathrm{bc}$ & $45.33 \mathrm{bc}$ & $5.36 \mathrm{c}$ & $1.29 \mathrm{c}$ & $110.89 \mathrm{de}$ & $8.66 \mathrm{~d}$ \\
\hline ER-8 & $27.91 \mathrm{~cd}$ & 42.48 bc & $45.19 \mathrm{bc}$ & $5.38 \mathrm{c}$ & $1.04 \mathrm{~cd}$ & $175.90 \mathrm{~cd}$ & $8.79 \mathrm{~d}$ \\
\hline ER-9 & 35.67 a & $28.69 \mathrm{~d}$ & $46.15 \mathrm{~b}$ & $5.47 \mathrm{~d}$ & $0.63 \mathrm{~d}$ & $11.96 \mathrm{e}$ & $8.97 \mathrm{~d}$ \\
\hline ER-10 & $33.45 \mathrm{ab}$ & $38.89 \mathrm{c}$ & $44.65 \mathrm{bc}$ & $5.53 \mathrm{~d}$ & $0.98 \mathrm{~cd}$ & $14.74 \mathrm{e}$ & $8.53 \mathrm{~d}$ \\
\hline SEM ** & 0.784 & 1.697 & 0.927 & 0.032 & 0.173 & 52.280 & 0.251 \\
\hline
\end{tabular}

*MDA: Malonaldehyde, ${ }^{\text {a-e }}$ : Means that do not share any letter in the same column are significantly different $(p<0.05) .{ }^{* *}$ SEM: Standard error of the mean 
Table 2. Free fatty acid (FFA) concentrations $(\mathrm{mg} / 100 \mathrm{~g} \mathrm{dm})$ of naturally fermented sausages.

\begin{tabular}{|c|c|c|c|c|c|c|c|c|c|c|c|c|c|c|c|c|c|c|c|c|c|}
\hline \multirow{2}{*}{$\begin{array}{l}\text { FFA } \\
\text { C14:0 }\end{array}$} & \multicolumn{2}{|l|}{ ER-1 } & \multicolumn{2}{|c|}{ ER-2 } & \multicolumn{2}{|c|}{ ER-3 } & \multicolumn{2}{|l|}{ ER-4 } & \multicolumn{2}{|c|}{ ER-5 } & \multicolumn{2}{|c|}{ ER-6 } & \multicolumn{2}{|c|}{ ER-7 } & \multicolumn{2}{|l|}{ ER-8 } & \multicolumn{2}{|c|}{ ER-9 } & \multicolumn{2}{|l|}{ ER-10 } & \multirow{2}{*}{$\begin{array}{r}\text { SEM }^{* *} \\
2.34\end{array}$} \\
\hline & 34.2 & $a$ & 16.5 & $\mathrm{C}$ & 19.3 & c & 26.9 & $b$ & 15.0 & c & 13.5 & C & 20.0 & $\mathrm{C}$ & 15.5 & $\mathrm{c}$ & 18.4 & c & 39.3 & $a$ & \\
\hline C16:0 & 407.1 & $a$ & 249.8 & $\mathrm{~cd}$ & 218.8 & $\mathrm{~cd}$ & 268.5 & c & 223.3 & $\mathrm{~cd}$ & 201.3 & de & 224.0 & $\mathrm{~cd}$ & 159.2 & $\mathrm{e}$ & 195.5 & de & 341.5 & b & 20.11 \\
\hline C18:0 & 212.6 & $a$ & 132.2 & $\mathrm{bc}$ & 98.9 & d & 141.1 & $b$ & 93.2 & de & 97.2 & de & 104.4 & $\mathrm{~cd}$ & 69.8 & $\mathrm{e}$ & 86.8 & de & 145.4 & $b$ & 9.70 \\
\hline SFA $^{*}$ & 653.9 & $a$ & 398.5 & $\mathrm{~cd}$ & 337.0 & cde & 436.5 & $\mathrm{bc}$ & 297.8 & de & 276.8 & e & 348.4 & cde & 244.5 & $\mathrm{e}$ & 300.6 & $\mathrm{de}$ & 526.2 & $b$ & 36.64 \\
\hline C16:1 & 81.5 & $\mathrm{~b}$ & 51.0 & $d$ & 43.6 & de & 99.4 & $a$ & 47.7 & de & 42.4 & de & 36.1 & ef & 36.8 & ef & 29.0 & $f$ & 67.2 & c & 4.19 \\
\hline C18:1 & 1571.3 & $a$ & 821.1 & $d$ & 710.3 & de & 1347.0 & $b$ & 646.6 & def & 688.9 & de & 571.5 & efg & 476.0 & $\mathrm{fg}$ & 387.5 & $g$ & 1100.4 & c & 68.49 \\
\hline $\mathrm{C} 20: 1$ n9 & 33.2 & $a$ & 12.9 & $\mathrm{~cd}$ & 12.1 & $\mathrm{~cd}$ & 25.8 & $\mathrm{~b}$ & 11.2 & $\mathrm{~cd}$ & 17.0 & c & 12.9 & $\mathrm{~cd}$ & 9.6 & $d$ & 7.8 & d & 10.9 & $\mathrm{~cd}$ & 2.28 \\
\hline MUFA & 1685.9 & $a$ & 885.0 & c & 766.0 & $\mathrm{~cd}$ & 1472.1 & $a$ & 698.7 & cde & 731.2 & cde & 620.6 & def & 522.4 & ef & 424.3 & $f$ & 1178.4 & $b$ & 74.31 \\
\hline C18:2 n6 & 708.7 & $a$ & 346.8 & cde & 357.2 & cde & 428.9 & $c$ & 319.9 & def & 307.7 & def & 367.3 & $\mathrm{~cd}$ & 246.5 & $f$ & 267.9 & ef & 587.1 & $b$ & 32.46 \\
\hline $\mathrm{C} 18: 3$ n3 & 45.3 & $a$ & 17.3 & $\mathrm{~cd}$ & 22.2 & c & 32.6 & $b$ & 19.8 & $\mathrm{~cd}$ & 19.1 & $\mathrm{~cd}$ & 19.5 & $\mathrm{~cd}$ & 14.9 & $\mathrm{~d}$ & 15.3 & $d$ & 32.8 & $\mathrm{~b}$ & 2.10 \\
\hline $\mathrm{C} 20: 2 n 6$ & 25.6 & $a$ & 10.4 & ef & 11.3 & de & 17.0 & $\mathrm{bc}$ & 11.7 & de & 13.8 & $\mathrm{~cd}$ & 14.9 & $\mathrm{C}$ & 9.5 & ef & 7.7 & $f$ & 19.0 & $\mathrm{~b}$ & 1.07 \\
\hline $\mathrm{C} 20: 3$ n6 & 10.6 & $a$ & 8.2 & $\mathrm{bc}$ & 5.0 & ef & 6.2 & de & 4.8 & ef & 4.7 & ef & 6.9 & $\mathrm{~cd}$ & 4.1 & $f$ & 4.6 & ef & 8.8 & $\mathrm{~b}$ & 0.55 \\
\hline C20:4 n6 & 55.0 & $a$ & 43.1 & $\mathrm{~b}$ & 30.4 & c & 29.1 & $\mathrm{~cd}$ & 28.4 & $\mathrm{~cd}$ & 29.6 & $\mathrm{~cd}$ & 43.9 & $\mathrm{~b}$ & 22.1 & $\mathrm{~d}$ & 31.6 & c & 56.8 & a & 2.76 \\
\hline $\mathrm{C} 22: 4$ n6 & 7.0 & $a$ & 5.0 & $\mathrm{bc}$ & 4.3 & cde & 5.1 & $\mathrm{bc}$ & 3.9 & de & 4.4 & $\mathrm{~cd}$ & 5.9 & $\mathrm{~b}$ & 3.4 & $\mathrm{e}$ & 4.1 & cde & 7.4 & a & 0.34 \\
\hline $\mathrm{C} 20: 5 n 3$ & 1.5 & $a$ & 1.1 & $\mathrm{bc}$ & 0.8 & de & 1.2 & $\mathrm{~b}$ & 0.8 & cde & 0.6 & e & 1.1 & bcd & 0.6 & $\mathrm{e}$ & 0.7 & e & 1.2 & $b$ & 0.11 \\
\hline $\mathrm{C} 22: 5 n 3$ & 14.1 & $a$ & 8.0 & $\mathrm{bc}$ & 6.6 & $\mathrm{~cd}$ & 12.7 & $a$ & 6.2 & $\mathrm{~cd}$ & 7.9 & $\mathrm{bc}$ & 9.8 & $\mathrm{~b}$ & 5.9 & $\mathrm{~d}$ & 7.7 & $\mathrm{~cd}$ & 14.6 & $a$ & 0.67 \\
\hline $\mathrm{C} 22: 6$ n3 & 3.3 & $a$ & 1.1 & $d$ & 0.9 & $d$ & 2.0 & $c$ & 0.8 & $d$ & 0.9 & $d$ & 1.8 & $c$ & 0.7 & $\mathrm{~d}$ & 1.8 & c & 2.6 & $b$ & 0.17 \\
\hline PUFA & 871.3 & $a$ & 441.0 & cde & 438.8 & cde & 534.7 & c & 396.3 & def & 388.8 & def & 471.2 & $\mathrm{~cd}$ & 307.7 & $f$ & 341.4 & ef & 730.3 & $b$ & 39.38 \\
\hline Total & 3211.1 & $a$ & 1724.6 & $\mathrm{~cd}$ & 1541.8 & $\mathrm{~cd}$ & 2443.3 & $\mathrm{~b}$ & 1848.7 & c & 1399.4 & $\mathrm{de}$ & 1440.1 & cde & 1074.6 & $\mathrm{e}$ & 1066.4 & e & 2434.9 & $b$ & 151.39 \\
\hline
\end{tabular}


Table 3. Volatile compounds in the headspace of naturally fermented sausages (GC-FID area units expressed as the mean of three replicates from each manufacturer).

\begin{tabular}{|c|c|c|c|c|c|c|c|c|c|c|c|c|c|c|c|c|c|c|c|c|c|c|c|}
\hline \multirow{2}{*}{$\begin{array}{l}7 \mathrm{KI} \\
8\end{array}$} & \multirow{2}{*}{ RI } & \multirow{2}{*}{$\begin{array}{l}\text { Compound/origin } \\
\text { Lipid auto-oxidation }\end{array}$} & \multicolumn{2}{|l|}{ ER-1 } & \multicolumn{2}{|l|}{ ER-2 } & \multicolumn{2}{|l|}{ ER-3 } & \multicolumn{2}{|l|}{ ER-4 } & \multicolumn{2}{|c|}{ ER-5 } & \multicolumn{2}{|c|}{ ER-6 } & \multicolumn{2}{|l|}{ ER-7 } & \multicolumn{2}{|l|}{ ER-8 } & \multicolumn{2}{|l|}{ ER-9 } & \multicolumn{2}{|l|}{ ER-10 } & \multirow[t]{2}{*}{ SEM } \\
\hline & & & & & & & & & & & & & & & & & & & & & & & \\
\hline 9500 & $\mathrm{a}$ & Pentane & 1.57 & $\mathrm{~cd}$ & 1.16 & d & 2.35 & $\mathrm{~cd}$ & 3.42 & $\mathrm{~cd}$ & 17.66 & a & 9.54 & $\mathrm{~b}$ & 3.06 & $\mathrm{~cd}$ & 1.63 & $\mathrm{~cd}$ & 6.26 & $\mathrm{~b}$ & 2.17 & $\mathrm{~cd}$ & 1.61 \\
\hline $1 \theta_{21}$ & $a$ & Propanal & 1.10 & $\mathrm{~cd}$ & 0.00 & $d$ & 17.30 & a & 0.63 & $d$ & 6.80 & $\mathrm{~b}$ & 4.01 & $\mathrm{bc}$ & 0.00 & $d$ & 0.00 & $d$ & 1.66 & $\mathrm{~cd}$ & 0.00 & d & 1.05 \\
\hline 1600 & $a$ & Hexane & 11.19 & $f$ & 30.88 & $a b c$ & 16.23 & ef & 21.03 & cdef & 30.12 & abcd & 25.46 & bcde & 19.77 & def & 26.14 & bcde & 33.86 & $a b$ & 36.98 & a & 3.52 \\
\hline 1214 & $a$ & 1-propanol & 16.41 & c & 10.39 & $d$ & 25.41 & $\mathrm{~b}$ & 8.53 & $\mathrm{de}$ & 5.73 & e & 10.41 & $d$ & 23.86 & $b$ & 18.11 & c & 49.31 & a & 7.67 & de & 1.11 \\
\hline 1825 & $a$ & Butanal & 0.00 & c & 0.00 & c & 1.01 & a & 0.00 & c & 0.80 & $a b$ & 0.50 & $\mathrm{~b}$ & 0.00 & c & 0.00 & c & 0.00 & c & 0.00 & c & 0.08 \\
\hline $\begin{array}{l}14 \\
15^{200}\end{array}$ & $a / a$ & $\begin{array}{l}\text { 2-Methylbutanal / } \\
\text { heptane }\end{array}$ & 0.00 & c & 3.38 & $\mathrm{bc}$ & 8.32 & $b$ & 2.05 & $\mathrm{bc}$ & 8.85 & $\mathrm{~b}$ & 6.83 & $\mathrm{bc}$ & 3.04 & $\mathrm{bc}$ & 1.62 & $\mathrm{bc}$ & 25.61 & a & 2.77 & $b c$ & 2.81 \\
\hline $16^{35}$ & $a$ & Pentanal & 8.84 & $\mathrm{bc}$ & 3.53 & c & 30.58 & a & 7.89 & $\mathrm{bc}$ & 25.50 & a & 12.48 & $\mathrm{~b}$ & 9.65 & $\mathrm{bc}$ & 6.50 & $\mathrm{bc}$ & 7.96 & $\mathrm{bc}$ & 3.20 & c & 2.40 \\
\hline 1739 & $a / a$ & $\begin{array}{l}\text { Ethyl propionate / 2,3- } \\
\text { Pentanedione }\end{array}$ & 2.56 & c & 7.83 & $a b$ & 9.33 & a & 7.27 & $\mathrm{~b}$ & 2.62 & c & 7.87 & $a b$ & 9.17 & $a b$ & 9.50 & a & 2.60 & c & 3.25 & c & 0.70 \\
\hline 1895 & $\mathrm{a}$ & Propanoic acid & 0.00 & $d$ & 0.00 & $d$ & 0.00 & $d$ & 0.00 & $d$ & 0.00 & $d$ & 18.58 & $b$ & 0.00 & $d$ & 30.48 & a & 0.00 & $d$ & 4.85 & c & 0.52 \\
\hline 1800 & $a$ & Octane & 2.10 & c & 3.29 & $\mathrm{bc}$ & 4.88 & $\mathrm{bc}$ & 4.80 & $\mathrm{bc}$ & 22.87 & a & 12.39 & $\mathrm{~b}$ & 5.81 & $\mathrm{bc}$ & 3.50 & $\mathrm{bc}$ & 28.25 & a & 3.13 & $b c$ & 3.21 \\
\hline 2836 & a & Hexanal & 82.20 & c & 47.65 & c & 323.38 & a & 95.04 & bc & 359.65 & a & 181.92 & $\mathrm{~b}$ & 122.78 & $\mathrm{bc}$ & 96.14 & $\mathrm{bc}$ & 109.83 & $\mathrm{bc}$ & 62.48 & c & 31.93 \\
\hline $\begin{array}{l}21 \\
22\end{array}$ & $a / a$ & $\begin{array}{l}\text { 2-Hexenal (Z) / Isopentyl } \\
\text { acetate }\end{array}$ & 0.00 & $\mathrm{~h}$ & 1.77 & $\mathrm{~g}$ & 3.73 & e & 2.50 & efg & 9.40 & c & 12.49 & $b$ & 17.75 & a & 7.84 & $d$ & 2.30 & $\mathrm{fg}$ & 3.30 & ef & 0.46 \\
\hline $23^{39}$ & a & Heptanal & 23.09 & c & 16.84 & $\mathrm{~cd}$ & 40.62 & $\mathrm{~b}$ & 40.38 & $\mathrm{~b}$ & 67.90 & a & 38.77 & $\mathrm{~b}$ & 55.65 & a & 4.54 & $d$ & 38.54 & $\mathrm{~b}$ & 16.09 & $\mathrm{~cd}$ & 5.06 \\
\hline 2470 & $a / a$ & $\begin{array}{l}\text { Methional / Pentanoic } \\
\text { acid }\end{array}$ & 10.85 & a & 1.60 & $d$ & 5.20 & c & 0.88 & $d$ & 5.91 & c & 5.53 & c & 9.11 & $\mathrm{~b}$ & 1.75 & $d$ & 9.63 & $a b$ & 9.00 & $b$ & 0.44 \\
\hline $\begin{array}{l}25 \\
26\end{array}$ & $a / a$ & $\begin{array}{l}\text { 2-Heptenal (Z)/ } \\
\text { Butirolactone }\end{array}$ & 5.67 & bcd & 0.00 & d & 13.30 & $b$ & 3.19 & $\mathrm{~cd}$ & 12.90 & $b$ & 8.53 & $\mathrm{bc}$ & 7.70 & bcd & 3.66 & $\mathrm{~cd}$ & 30.27 & $a$ & 2.73 & $c d$ & 2.85 \\
\hline 27047 & $\mathrm{a}$ & Octanal & 3675.03 & a & 2552.22 & $\mathrm{bc}$ & 3705.44 & a & 1814.40 & $d$ & 2061.78 & $\mathrm{~cd}$ & 1565.85 & $d$ & 672.33 & e & 1664.07 & $d$ & 3174.85 & $a b$ & 3796.34 & a & 212.11 \\
\hline 28064 & $\mathrm{a}$ & Hexanoic acid & 219.36 & a & 139.44 & c & 177.86 & $\mathrm{~b}$ & 72.49 & e & 96.80 & $d$ & 59.43 & e & 76.55 & de & 139.00 & c & 173.64 & $\mathrm{~b}$ & 193.64 & $b$ & 8.09 \\
\hline 29075 & $a$ & 2,4-Heptadienal $(Z, Z)$ & 113.92 & a & 49.39 & c & 110.44 & $a b$ & 29.60 & $d$ & 14.85 & $d$ & 17.62 & $d$ & 47.06 & c & 24.14 & $d$ & 94.55 & $\mathrm{~b}$ & 119.99 & a & 5.51 \\
\hline 30116 & $\mathrm{a}$ & 2-Octenal (Z) & 3.49 & $d$ & 0.37 & e & 6.87 & $\mathrm{~b}$ & 2.30 & de & 6.73 & $\mathrm{bc}$ & 4.07 & $\mathrm{~cd}$ & 3.62 & $d$ & 2.29 & de & 26.41 & a & 1.52 & de & 0.93 \\
\hline 31151 & a & Nonanal & 81.38 & $\mathrm{bc}$ & 49.46 & $\mathrm{~cd}$ & 86.66 & $\mathrm{bc}$ & 40.33 & $d$ & 112.53 & $\mathrm{~b}$ & 110.36 & $\mathrm{~b}$ & 187.32 & a & 116.76 & $\mathrm{~b}$ & 177.02 & a & 57.08 & $\mathrm{~cd}$ & 12.97 \\
\hline 32159 & a & Heptanoic acid & 20.37 & $d$ & 24.62 & $\mathrm{~cd}$ & 27.98 & c & 258.87 & a & 11.30 & e & 10.77 & e & 28.25 & c & 12.61 & $\mathrm{e}$ & 10.47 & e & 50.44 & $b$ & 2.28 \\
\hline 33200 & a & Dodecane & 5.09 & $\mathrm{~cd}$ & 4.47 & de & 2.62 & ef & 5.57 & $\mathrm{bcd}$ & 1.11 & $\mathrm{fg}$ & 1.86 & $\mathrm{fg}$ & 10.77 & a & 0.00 & $g$ & 7.13 & $\mathrm{bc}$ & 7.27 & $b$ & 0.72 \\
\hline 34221 & a & 2-Nonenal (Z) & 2.67 & c & 4.26 & $\mathrm{bc}$ & 13.27 & $\mathrm{~b}$ & 3.13 & c & 3.47 & $\mathrm{bc}$ & 2.65 & $\mathrm{c}$ & 2.87 & c & 2.10 & c & 81.15 & a & 1.52 & c & 3.34 \\
\hline 35253 & $\mathrm{a} / \mathrm{a}$ & Octanoic acid/decanal & 64.83 & $a b$ & 45.66 & c & 49.91 & $\mathrm{bc}$ & 1.53 & $d$ & 57.38 & $\mathrm{bc}$ & 57.54 & $\mathrm{bc}$ & 41.07 & c & 80.48 & $a$ & 49.59 & $\mathrm{bc}$ & 76.53 & a & 5.69 \\
\hline 36326 & $\mathrm{a}$ & 2-Decenal (Z) & 3.66 & $\mathrm{bc}$ & 1.86 & de & 2.57 & cde & 1.70 & de & 3.95 & $\mathrm{bc}$ & 3.23 & bcd & 4.60 & $a b$ & 5.89 & $a$ & 3.92 & $\mathrm{bc}$ & 1.01 & e & 0.61 \\
\hline $3 \pi 344$ & $\mathrm{a}$ & 2-Undecanone & 5.58 & bcd & 5.87 & $\mathrm{bc}$ & 3.57 & cde & 7.93 & $b$ & 2.69 & e & 2.18 & e & 3.29 & de & 28.41 & $a$ & 6.80 & $\mathrm{~b}$ & 7.17 & $b$ & 1.02 \\
\hline 38440 & $b$ & Decanoic acid & 35.21 & c & 31.53 & $\mathrm{~cd}$ & 49.24 & $\mathrm{~b}$ & 35.90 & c & 28.24 & de & 21.21 & $f$ & 54.36 & a & 32.54 & $\mathrm{~cd}$ & 23.66 & ef & 33.68 & c & 1.71 \\
\hline $\begin{array}{l}39 \\
40\end{array}$ & & $\begin{array}{l}\text { Bacterial metabolism } \\
\text { Lipid } \beta \text {-oxidation }\end{array}$ & & & & & & & & & & & & & & & & & & & & & \\
\hline $\begin{array}{l}4 \$ 37 \\
42\end{array}$ & a & 2-Butanone & 13.24 & $\mathrm{~b}$ & 17.24 & a & 18.23 & a & 8.39 & c & 5.97 & $\mathrm{~cd}$ & 4.20 & $d$ & 8.08 & a & 9.25 & c & 0.00 & e & 7.90 & c & 1.14 \\
\hline
\end{tabular}


$1.55 \mathrm{~d}$

Carbohydrate fermentation

$\begin{array}{lr}53.27 & \mathrm{~d} \\ \text { Diacetyl } & 0.00 \mathrm{e}\end{array}$

a 2-Butanol

Acetic acid Amino acid catabolism

2-Methylpropanal

Benzene

2-Methyl-1-propanol

3-Methylbutanal

Dimethyl disulfide

2-Methylbutanoic acid

Benzaldehyde

$$
3.52 \mathrm{f}
$$

$0.00 \mathrm{f}$

98.06 a

Phenol

$52.13 \mathrm{a}$

Benzeneacetaldehyde

69.76 c

Staphylococci esterase activity

a Methyl acetate

Ethyl acetate

Methyl propanoate

Propyl acetate

Methyl butanoate

Ethyl 2-methyl

propanoate
Toluene / Methyl 2-

hydroxy-propanoate

Methyl 3-methy

butanoate

Ethyl butanoate

Methyl pentanoate Ethyl 2-hydroxy-

a/a propanoate /2-methyl pirazine

$513.20 \mathrm{~b}$

358.71 e

$8.84 a$

$994.51 \mathrm{~b}$

$10.67 \mathrm{~b}$

$17.35 \mathrm{c}$

$22.83 \mathrm{c}$

Ethyl 2-methylbutanoate

Ethyl 3-methylbutanoate

Ethyl pentanoate

Methyl hexanoate

Ethyl heptanoate

356.77 a

808.20 b
$1902.84 \mathrm{~cd}$

$$
1.42 \mathrm{~cd}
$$

$0.55 \mathrm{de}$

4.48 def

$2.72 \mathrm{~cd}$

$466.30 \mathrm{ab}$

$26.84 \mathrm{~cd}$

$131.50 \mathrm{~cd}$

$112.95 \mathrm{bc}$

$71.52 \mathrm{ab}$

$\begin{array}{rlrllll}0.00 & \text { e } & 20.46 & \text { a } & 0.50 & \text { de } & 2.83 \text { b } \\ 0.00 & \text { d } & 14.28 & \text { b } & 2.32 & \text { d } & 13.09 \text { bc } \\ 31.20 & \text { a } & 28.50 & \text { ab } & 8.50 & \mathrm{f} & 17.50 \mathrm{de} \\ & & & & & & \\ 100.10 & \text { b } & 369.43 & \text { a } & 32.63 & \text { e } & 51.19 \text { de } \\ 2.33 & \text { cd } & 23.91 & \text { a } & 0.00 & \text { e } & 2.99 \mathrm{c} \\ 7.05 & \text { cdef } & 7.44 & \text { cde } & 5.46 & \text { ef } & 9.34 \text { bc }\end{array}$

$0.63 \mathrm{~d}$

$1.03 \mathrm{~d}$

$21.63 \mathrm{~cd}$

\section{$8.32 \mathrm{f}$ \\ $3.23 \mathrm{c}$}

7.70 cde

1767.46 cd 273.76 f 1699.16 d

1.37

$0.40 \mathrm{e}$

$9.52 \mathrm{c}$

2.20 bc $\quad 0.81 d$

8.68 cde

$13.80 \mathrm{bcd}$

$76.96 \mathrm{~b}$

287.05 de

$19.69 \mathrm{e}$

55.64 c

$345.55 \mathrm{~d}$

843.83 a

$16.67 \mathrm{fg}$

$0.52 \mathrm{~cd}$

$618.56 \mathrm{~cd}$

$2.95 \mathrm{f}$

99.70 ef

30.78 c

211.14 a

$39.21 d$

44.37 b

268.45 b

$19.68 \mathrm{c}$

$12.23 \mathrm{~b}$

$647.45 \mathrm{c}$

$0.00 \mathrm{~d}$
$0.00 \mathrm{f}$

10.54 bc

173.41 a

04.63

248.06 e

54.81 a

18.76 efg

$0.60 \mathrm{f}$

41.53 b $\quad 30.31$

$1.15 \mathrm{c} \quad 0.34 \mathrm{~d}$

1024.70 ab $458.01 \mathrm{e}$

$0.00 \mathrm{~g}$

4.15 ef

$79.08 \mathrm{f} \quad 166.55 \mathrm{~b}$

$11.21 \mathrm{c}$

$1.30 \mathrm{f}$

77.41 a

0.00 e

$203.96 \mathrm{c}$

$0.00 \mathrm{e}$

$0.96 \mathrm{f}$

984.35 a

$6.83 \mathrm{a}$
67.71 b

$90.16 \mathrm{~cd}$

$43.25 \mathrm{~d}$

$46.68 \mathrm{~b}$

150.27 e

$22.21 \mathrm{c}$

6.30

$622.78 \mathrm{c}$

2.74 bc
$1309.27 \mathrm{e}$

$1.29 \mathrm{~d}$

$1.35 \mathrm{ab}$

$18.43 \mathrm{~b}$

$2.79 \mathrm{de}$

$9.06 \mathrm{~cd}$

$18.83 \mathrm{bc}$

17.49 cde

$136.10 \mathrm{f}$

$22.64 \mathrm{de}$

$10.92 \mathrm{fg}$

$218.83 \mathrm{e}$

$38.05 \mathrm{f}$

$44.80 \mathrm{ab}$

$0.49 \mathrm{~cd}$

$1127.54 \quad$ a

$$
0.00 \mathrm{~g}
$$

153.70 bc

$36.05 \mathrm{c}$

46.91 e

76.73 a

$4.32 \mathrm{e}$

$228.46 \mathrm{c}$

3.75 de

$4.02 \mathrm{e}$

868.28 ab

7.73 a
5.44 cdef

$11.43 \mathrm{~cd}$

$10.92 \mathrm{de}$

$158.85 \mathrm{f}$

25.36 cde

$39.90 \mathrm{~d}$

654.42 a 413.81 de

47.02 a

$0.64 \mathrm{~cd}$

$711.16 \mathrm{c}$

5.70 de

161.25 b

68.96 b

$118.94 \mathrm{~b}$

61.59 bc

$20.04 \mathrm{~cd}$

164.27 de

$18.91 \mathrm{c}$

$8.62 \mathrm{C}$

$3.72 b$

$$
1.10 \mathrm{~d}
$$

24.50 bc

74.34 C

$1.09 \mathrm{de}$

6.02 def

$2442.95 \mathrm{~b}$

$1.24 \mathrm{~d}$

$0.78 \mathrm{~cd}$

$16.53 \mathrm{~b}$

3.90 ef

27.98 b

$9.86 \mathrm{e}$

$99.54 \mathrm{f}$

$4.90 \mathrm{f}$

$238.20 \quad a$

635.17 a

965.44 a

23.09 de

$2.42 \mathrm{~b}$

538.49 de

9.40 bc

162.06 b

66.40

202.75

$50.85 \mathrm{~cd}$

$68.10 \quad a$

220.46 c

$34.30 \mathrm{~b}$

$15.13 a$

$668.40 \mathrm{c}$

$3.83 \mathrm{~b}$

$\begin{array}{rlrlrlr}0.47 & \text { de } & 1.60 & \text { c } & 0.55 & \text { de } & 1.96 \\ 10.27 \text { c } & 25.27 & \text { a } & 0.00 & \text { d } & 0.92 \\ 0.00 & \text { g } & 13.75 & \text { e } & 28.55 & \text { ab } & 1.93 \\ & & & & & & \\ 32.89 & \text { e } & 43.12 & \text { de } & 4.56 & \text { f } & 6.45 \\ 0.00 & \text { e } & 0.80 & \text { e } & 9.27 & \text { b } & 0.46 \\ 8.71 & \text { bcd } & 11.44 & \text { ab } & 12.87 & \text { a } & 1.09 \\ 1396.48 \text { e } & 1996.68 & \text { c } & 3292.36 & \text { a } & 98.41\end{array}$

$0.86 \mathrm{~d}$

0.45 e

28.52 a

$0.77 \mathrm{f}$

$0.00 \mathrm{~d}$

$30.21 \mathrm{~cd}$

$149.44 \mathrm{f}$

22.03 e

$5.23 \mathrm{~g}$

314.88 d

581.71 bc

20.44 ef

$0.67 \mathrm{~cd}$

470.45 e

13.50 a

194.23

$78.67 \quad b$

184.33 a 
$133.93 \mathrm{~cd}$

Methyl benzeneacetate

87.75 d

$157.65 \mathrm{~b}$

132.78 cd 112.19 cde

104.67 cde

$0.00 \mathrm{~d}$

202.73 a

$2.96 \mathrm{~g}$

$2.87 \mathrm{~g}$

$41.79 \mathrm{f}$

$275.23 \mathrm{ab}$

293.81 a

155.56 b

$233.49 \mathrm{~b}$

242.68 a

$146.16 \mathrm{c}$

77.06 e

14.16

Methyl nonanoate

45.39

76.40 a

$1.47 \mathrm{~cd}$

$0.36 \mathrm{~d}$

$3.16 \mathrm{~cd}$

$1.78 \mathrm{~cd}$

$5.00 \mathrm{~g}$

$61.80 \mathrm{e}$

12.48 e $\quad 3.67 \mathrm{f}$

$34.94 \mathrm{~d}$

$2.95 \mathrm{~cd}$

Methyl decanoate

$4.13 \mathrm{bc}$

$0.25 \mathrm{~d}$

$6.70 \mathrm{ab}$

$1.50 \mathrm{~cd}$

$1.96 \mathrm{~cd}$

$6.11 \mathrm{~b}$

$13.34 \mathrm{e}$

5.97 b

38.37

$2.13 \mathrm{~cd}$

30.41 a

$14.35 \mathrm{c}$

28.74 a

33.36

21.89 b

87.02 b

$8.85 \mathrm{f}$

$59.57 \mathrm{c}$

9.58 ef

$64.61 \mathrm{c}$

$107.90 \quad a$

$90.13 \mathrm{~b}$

9.70

$58.03 \mathrm{~b}$

$1.28 \mathrm{~d}$

9.07

$7.84 \mathrm{~d}$

Derived from spices

1245 a $\alpha$-Pinene

13003 a $\beta$-Myrcene

14026 a/a Ethyl hexanoate / 3-

$$
15
$$

16037 a/a/a $\begin{aligned} & \alpha \text {-terpinene / trimethyl } \\ & \text { pyrazine / octanone }\end{aligned}$

$1 \pi 052$ a p-Cymene

18051 a Limonene

19148 a/a Linalol / Methyl benzoate

239.98 b

$44.57 \mathrm{~d}$

2312.18 a

$35.09 \mathrm{~d}$

$26.25 \mathrm{~d}$

$10.38 \mathrm{~d}$

$29.79 \mathrm{~d}$

1183.03 d 1978.21

$814.07 \mathrm{e}$

$493.89 \mathrm{f}$

$379.68 \mathrm{f}$

$153.79 \mathrm{~g}$

572.49

165.10

26.46 de

$303.84 a$

764.95 c

979.80 b $\quad 687.97$ c

$423.65 \mathrm{~d}$

362.09 d

$301.01 \mathrm{~d}$

$690.27 \mathrm{c}$

$1635.03 \mathrm{c}$

351.95 a

2070.80 ab

859.67 bc 772.38 c

$14.10 \mathrm{~d}$

443.25 a

$37.71 \mathrm{C}$

$18.66 \mathrm{~d}$

$7.40 \mathrm{~d}$

$9.38 d$

35.19

$174.12 \mathrm{~cd}$

107.64 e

130.12 de

$199.28 \mathrm{c}$

64.67

79.23

468.55 a $\quad 361.33$ b

450.98 a

271.96

$180.54 \mathrm{c}$

$178.40 \mathrm{C}$

$98.25 \mathrm{c}$

$85.02 \mathrm{C}$

$428.40 \quad$ a

$328.60 \mathrm{~b}$

46.38

$13.09 \mathrm{ab} \quad 15.73 \mathrm{a}$

$\begin{array}{ll}85.74 & a\end{array} \quad 3.34 \mathrm{~g}$

$91 \mathrm{~cd}$

$5.88 \mathrm{~d}$

520.54 a

295.87 b

50.21 ef

$600.82 \mathrm{c}$

751.77 bc

213.05 e

$429.92 \mathrm{~d}$

10.24 bc

$59.55 \mathrm{~d}$

$820.18 a b$

985.71 a

\begin{tabular}{rlrlr}
32.58 & a & 0.65 & c & 1.41 \\
30.31 & a & 17.59 & bc & 2.44 \\
26.30 & b & 3.41 & d & 2.15 \\
5.10 & b & 3.96 & bc & 0.97 \\
8.37 & b & 7.66 & b & 0.48 \\
4.73 & c & 3.32 & d & 0.29 \\
0.58 & cde & 1.62 & b & 0.19 \\
195.37 & a & 64.83 & cde & 10.51 \\
\hline
\end{tabular}

Unknown origin, meat or food contaminants

24

a Ethyl benzene

$2.40 \mathrm{c} \quad 9.47 \mathrm{~b}$

3.23 c $\quad 2.38 \mathrm{c}$

1.72

$2.03 \mathrm{c}$

0.74

$7.16 \mathrm{~d}$

$8.57 \mathrm{~cd}$

$5.12 \mathrm{~b}$

$4.23 \mathrm{c}$

$6.52 \mathrm{~b}$

0.49 de

52.63 def

$22.07 \mathrm{fg}$

$91.24 \mathrm{bc}$

64.83 cde

0.51

A. Kovats indices calculated for DB-624 capillary column (J\&W Scientific: $60 \mathrm{~m}, 0.32 \mathrm{~mm}$ i.d., $1.8 \mu \mathrm{m}$ film thickness) installed on a gas chromatograph equipped with FID detector. ${ }^{a-h}$ : Means that do not share any letter in a row are significantly different $(p<0.05)$. ${ }^{*}$ SEM: Standard error of the mean. ${ }^{C}$ Reliability of identification: a, mass spectrum and retention time identical with an authentic standard; $b$, tentative identification by mass spectrum 
Table 4. Odour-active compounds identified in the HS of dry fermented sausages.

\begin{tabular}{|c|c|c|c|c|}
\hline $\mathbf{N}^{*}$ & $\mathbf{I K}^{\star \star *}$ & Compound $^{* * *}$ & GC-O descriptor & $\mathrm{DF}^{* * * *}$ \\
\hline 1 & 472 & Methanethiol & Rotten & 7 \\
\hline 2 & 590 & 2-Methylpropanal & Fresh, cologne & 5 \\
\hline 3 & 630 & Diacetyl & Butter, caramel & 5 \\
\hline 4 & 642 & Ethyl acetate & Vegetal & 4 \\
\hline 5 & 702 & Acetic acid & Vinegar & 17 \\
\hline 6 & 740 & 2,3-Pentanedione & Sweet, milky & 5 \\
\hline 7 & 753 & Methyl butanoate & Fruity & 4 \\
\hline 8 & 784 & Ethyl 2-methylpropanoate & Strawberry & 12 \\
\hline 9 & 802 & Methyl 3-methylbutanoate & Fruity & 11 \\
\hline 10 & 824 & Ethyl butanoate & Strawberry, fruity & 17 \\
\hline 11 & 835 & Hexanal & Fresh cut grass & 12 \\
\hline 12 & 861 & Ethyl 2-hydroxy-propanoate & Fresh & 4 \\
\hline 13 & 870 & Ethyl 2-methylbutanoate & Fruity & 9 \\
\hline 14 & 874 & Ethyl 3-methylbutanoate & Fruity, floral & 8 \\
\hline 15 & 872 & Butanoic acid & Cheese & 11 \\
\hline 16 & 898 & Unknown 1 & Meat broth, savory & 20 \\
\hline 17 & 924 & Ethyl pentanoate & Floral, fresh, fruity & 4 \\
\hline 18 & 937 & Heptanal & Herbal & 5 \\
\hline 19 & 963 & Unknown 2 & Roasted nuts, toasted & 15 \\
\hline 20 & 966 & Methional & Cooked potato & 15 \\
\hline 21 & 1007 & 2-Heptenal (Z) & Unpleasant, cabbage & 12 \\
\hline 22 & 1020 & 1-Octen-3-ol & Mushroom & 20 \\
\hline 23 & 1025 & Ethyl hexanoate & Flowery, sweet & 10 \\
\hline 24 & 1031 & a-Terpinene & wood, metallic & 14 \\
\hline 25 & 1045 & Octanal & Citric & 4 \\
\hline 26 & 1109 & Benzeneacetaldehyde & Roses & 16 \\
\hline 27 & 1135 & Unknown 3 & Toasted, old wood, burnt hair & 13 \\
\hline 28 & 1147 & Methyl benzoate & Fruity, sweet, waxy, metallic & 9 \\
\hline 29 & 1162 & Heptanoic acid & Fresh, herbal & 6 \\
\hline 30 & 1172 & Unknown 4 & Woody, pine & 12 \\
\hline 31 & 1178 & Unknown 5 & Roasted nuts, toasted & 14 \\
\hline 32 & 1189 & Unknown 6 & Mustiness, woody & 10 \\
\hline 33 & 1190 & 4-Methyl phenol & Stable & 16 \\
\hline 34 & 1195 & Phenylethyl alcohol & Roses & 9 \\
\hline 35 & 1201 & Unknown 7 & Mustiness & 9 \\
\hline 36 & 1222 & Unknown 8 & Wood, toasted, herbal & 15 \\
\hline 37 & 1236 & Methyl benzeneacetate & Caramel, sweet, toffee & 7 \\
\hline 38 & 1245 & Unknown 9 & Toasted, coffee & 9 \\
\hline 39 & 1286 & Unknown 10 & Glue, dissolvent & 14 \\
\hline 40 & 1400 & Unknown 11 & Wood, pistachio, spicy & 8 \\
\hline 41 & 1424 & Ethyl decanoate & Fruity & 4 \\
\hline 42 & 1443 & Caryophyllene & Spicy, cloves & 10 \\
\hline
\end{tabular}

${ }^{*} \mathrm{~N}$ : number of compound as shown in figure 1. ${ }^{* *} \mathrm{IK}$ : Kovats index calculated for DB-624 capillary column (J\&W Scientific $60 \mathrm{~m} \times 0.32 \mathrm{~mm}$ i.d., film thickness $1.8 \mu \mathrm{m}$ ) installed on a gas chromatograph equipped with a flame ionization detector (FID) and a sniffing port. ${ }^{* * *}$ Identification by mass spectrum, coincidence with the LRI of an authentic standard and by coincidence of the assessors's descriptors with those described in the Fenaroli's handbook of flavour ingredients (Burdock, 2002). ${ }^{* * * *}$ DF Detection frequency value. 
Table 5. Consumer analysis (hedonic test) of naturally fermented (ER) sausages.

\begin{tabular}{lcrcccc}
\hline Samples & Appearance & Aroma & Toughness/hardness & Juiciness & \multicolumn{1}{c}{ Taste } & Overall quality \\
\hline ER-1 & $6.24 \mathrm{ab}$ & $6.35 \mathrm{a}$ & $6.38 \mathrm{ab}$ & $6.57 \mathrm{a}$ & $6.62 \mathrm{a}$ & $6.42 \mathrm{a}$ \\
ER-2 & $6.11 \mathrm{ab}$ & $6.46 \mathrm{a}$ & $6.24 \mathrm{ab}$ & $6.24 \mathrm{a}$ & $5.91 \mathrm{c}$ & $6.1 \mathrm{a}$ \\
ER-3 & $6.44 \mathrm{a}$ & $6.24 \mathrm{a}$ & $6.53 \mathrm{a}$ & $6.44 \mathrm{a}$ & $6.19 \mathrm{abc}$ & $6.16 \mathrm{a}$ \\
ER-4 & $4.94 \mathrm{c}$ & $6.39 \mathrm{a}$ & $4.97 \mathrm{c}$ & $5.57 \mathrm{~b}$ & $5.3 \mathrm{~d}$ & $5.01 \mathrm{~b}$ \\
ER-5 & $5.84 \mathrm{~b}$ & $5.67 \mathrm{~b}$ & $6.44 \mathrm{ab}$ & $6.44 \mathrm{a}$ & $6.34 \mathrm{abc}$ & $6.25 \mathrm{a}$ \\
ER-6 & $6.28 \mathrm{ab}$ & $6.48 \mathrm{a}$ & $5.97 \mathrm{~b}$ & $6.38 \mathrm{a}$ & $6.08 \mathrm{bc}$ & $6.08 \mathrm{a}$ \\
ER-7 & $6.42 \mathrm{a}$ & $6.23 \mathrm{a}$ & $6.23 \mathrm{ab}$ & $6.55 \mathrm{a}$ & $6.57 \mathrm{ab}$ & $6.37 \mathrm{a}$ \\
ER-8 & $6.15 \mathrm{ab}$ & $6.29 \mathrm{a}$ & $6.34 \mathrm{ab}$ & $6.38 \mathrm{a}$ & $5.84 \mathrm{c}$ & $6.01 \mathrm{a}$ \\
ER-9 & $6.2 \mathrm{ab}$ & $6.3 \mathrm{a}$ & $6.06 \mathrm{ab}$ & $6.33 \mathrm{a}$ & $6.26 \mathrm{abc}$ & $6.12 \mathrm{a}$ \\
ER-10 & $5.23 \mathrm{c}$ & $6.14 \mathrm{a}$ & $6.53 \mathrm{a}$ & $6.61 \mathrm{a}$ & $6.24 \mathrm{abc}$ & $6.42 \mathrm{a}$ \\
SEM & 0.175 & 0.156 & 0.179 & 0.16 & 0.185 & 0.176 \\
\hline a-d
\end{tabular}

a-d: Means that do not share any letter in a column are significantly different $(p<0.05) .{ }^{*}$ SEM:

Standard error of the mean. ${ }^{1}$ Scale used: 9-point hedonic. 


1
2
3
4
5
6
7
8
9
10
11
12
13
14
15
16
17
18
19
20
21
22
23
24
25
26
27
28
29
30
31
32
33
34
35
36
37
38
39
40
41
42
43
44
45
46
47
48
49
50
51
52
53
54
55
56
57
58
60

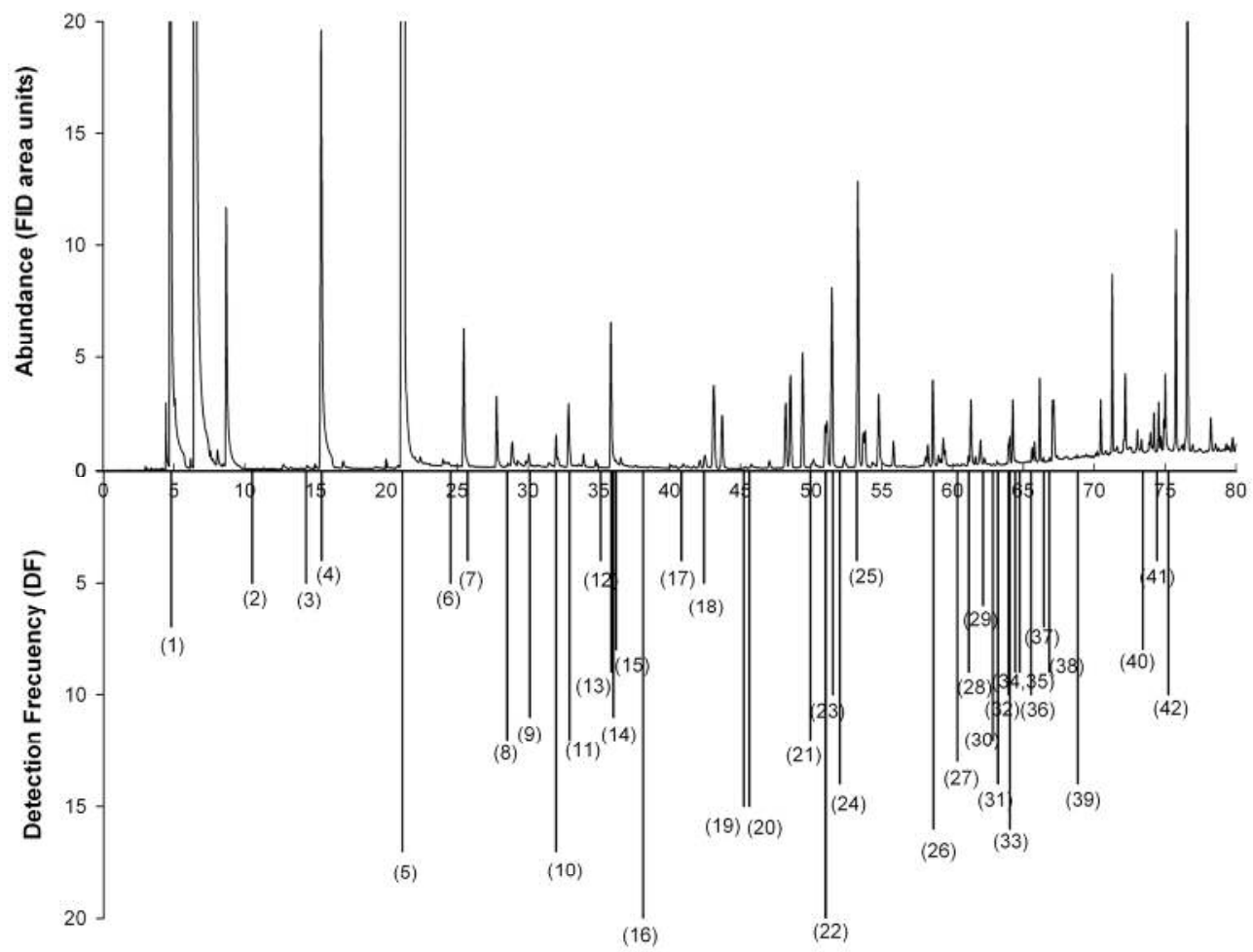

Aromagram of naturally fermented sausages. Numbers corresponds to the aroma described and indicated in table 4. $186 \times 156 \mathrm{~mm}(300 \times 300 \mathrm{DPI})$ 


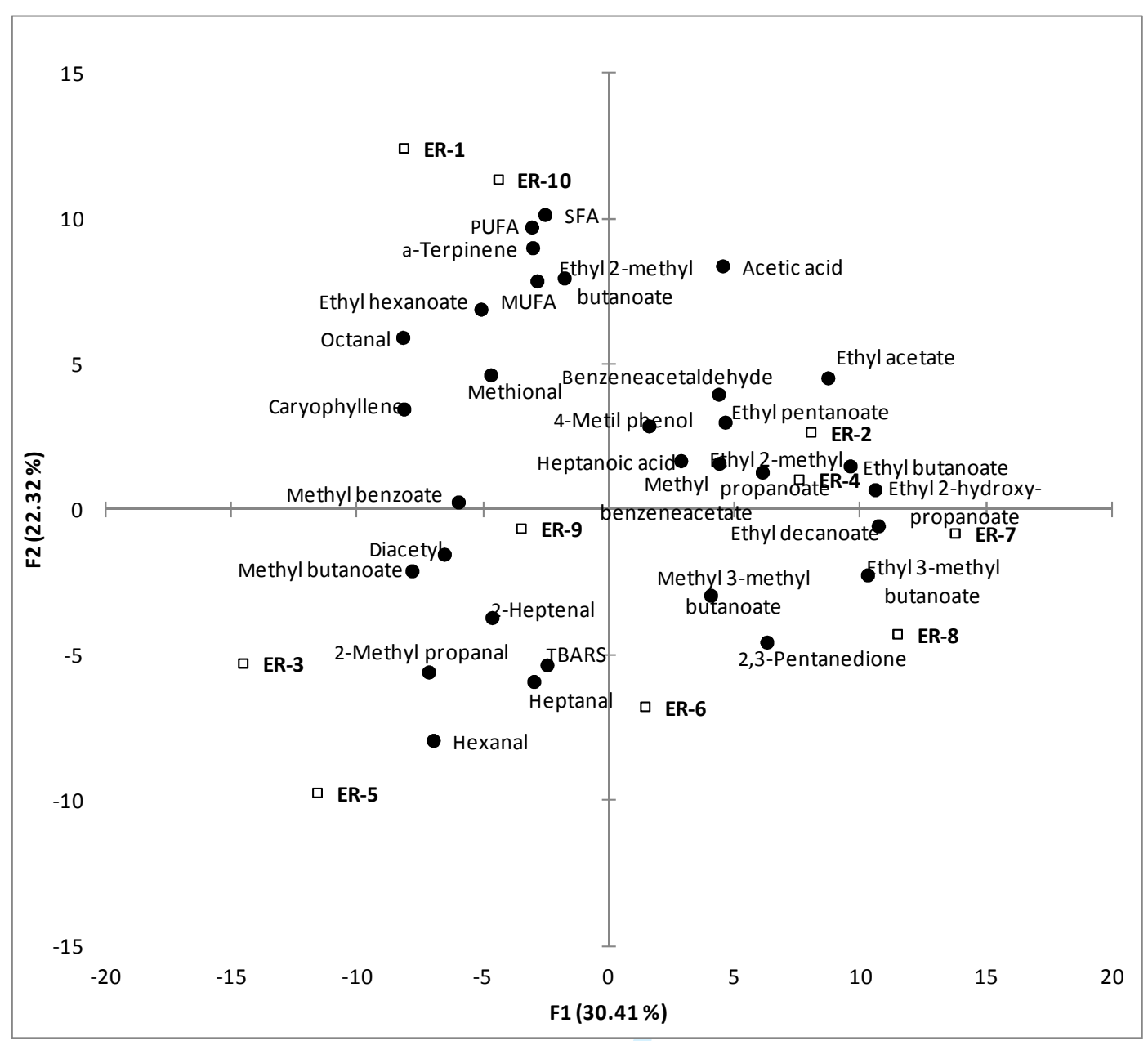

